\title{
腋窩動脈送血を用いた真性胸部大動脈瘤手術 一術後脳合併症予防の観点から-
}

\author{
内田徹 郎 箕 輪 隆 保坂 淳 小 鹿 雅 隆
乾 清 重渡辺隆夫 島 崎 靖 久
}

\begin{abstract}
大腿動脈を送血経路として用いる胸部大動脈瘤手術は広く行われているが, 体循環が逆行性ゆえの合併症が 危惧される。1996 年 9 月以降, 脳合併症予防目的に施行した腋窩動脈送血法による真性胸部大動脈瘤手術 12 例を検討した。症例は全例男性で手術時年齢は 65〜80 歳 (平均 72 歳). 術式は全弓部置換術 10 例, パッ チ形成術 2 例であった．腋窩動脈送血に関して，直接動脈にカニュレーションを行ったのが 2 例，人工血管 を縫着して行った症例が 10 例であった. 術前脳梗塞の既往を有する 1 例に術後脳梗塞を発症, 手術死亡と なった. 術後の軽度譫妄を 3 例に認めたが, 短期間で改善, 脳梗塞発症例以外は全例独歩退院した. 腋窩動 脈送血による順行性送血と広範囲に病変部を切除することを基本方針とした弓部全置換の積極的導入により 死亡率と脳合併症は低下し, 動脈硬化性病変が著しい本症でも比較的安全に手術が行いうると考えられる. 日心外会誌 31 巻 4 号：266-268（2002）
\end{abstract}

Keywords：真性胸部大動脈瘤，腋窩動脈送血，弓部大動脈全置換術

\begin{abstract}
Axillary Artery Perfusion in Arteriosclerotic Thoracic Aortic Aneurysm
Tetsuro Uchida, Takashi Minowa, Jun Hosaka, Masataka Koshika, Kiyoshige Inui, Takao Watanabe and Yasuhisa Shimazaki (Second Department of Surgery, Yamagata University School of Medicine, Yamagata, Japan)

Between 1996 to 2000, 12 patients with arteriosclerotic thoracic aortic aneurysm underwent surgery with cardiopulmonary bypass using the right axillary artery as an arterial inflow. All patients received total arch replacement with selective cerebral perfusion and deep hypothermic circulatory arrest. One patient with occlusion of the left carotid artery died of postoperative stroke. There were no postoperative complications or deaths related to axillary artery perfusion except for cerebrovascular accidents. Perfusion through the axillary artery, providing antegrade aortic flow, is a safe and effective procedure to avoid stroke owing to retrograde arterial perfusion. We believe that the axillary artery could be an alternative to conventional femoral artery cannulation in the setting of aortic arch operations. Jpn. J. Cardiovasc. Surg. $31: 266-$ $268(2002)$
\end{abstract}

真性胸部大動脈瘤に対する外科治療における最も大きな 問題点は脳合併症であり ${ }^{1)}$ ，大腿動脈からの逆行性送血や 高度の粥状硬化性病変を有する部位での手術操作が原因と して考えられている。こうした観点から，われわれは真性 胸部大動脈瘤に対し，体循環の送血を常に順行性に行いう る腋窩動脈送血を選択してきた。本稿では腋窩動脈送血法 による手術成績に関して術後脳合併症を中心として検討し た.

\section{手術}

最近われわれが行っている腋窩動脈送血法による大動脈 弓部置換の術式を図示する（図 1). 胸骨正中切開ならび に右鎖骨下を小切開する. 人工血管 $(8 \mathrm{~mm})$ を縫着した

2001 年 5 月 7 日受付, 2002 年 1 月 7 日採用

山形大学第 2 外科 $\bar{\top}$ 990-9585 山形市飯田西 2-2-2
右腋窩動脈送血と右房脱血による体外循環を開始，全身冷 却，心停止後，腕頭動脈を遮断，弓部大動脈を切開，左総 頸動脈と左鎖骨下動脈にそれぞれカニューレを挿入，3 分 枝灌流による脳分離体外循環を開始する，脳分離体外循環 の灌流量は 3 分枝合計で $10 \mathrm{ml} / \mathrm{kg} / \mathrm{min}$ ，最低直腸温は $22^{\circ} \mathrm{C}$ 前後に設定している。 大動脈末梢側吻合は open distal として elephant trunk 法 $(12 \mathrm{~cm})$ で行う. 人工血管 の側枝から下半身の体循環を再開，復温する．中枢側吻合 後, 大動脈遮断解除, 順次弓部 3 分枝の再建を行う．腋窩 動脈に縫着した人工血管は $5 \mathrm{~mm}$ 程度を残し切断, 閉鎖 する。

患 者

1996 年 9 月以降, 胸骨正中切開による脳分離体外循環 を用いた真性胸部大動脈溜に対する手術 12 例を対象とし た（表 1$)$. 破裂および切迫破裂などの緊急手術，左側開 


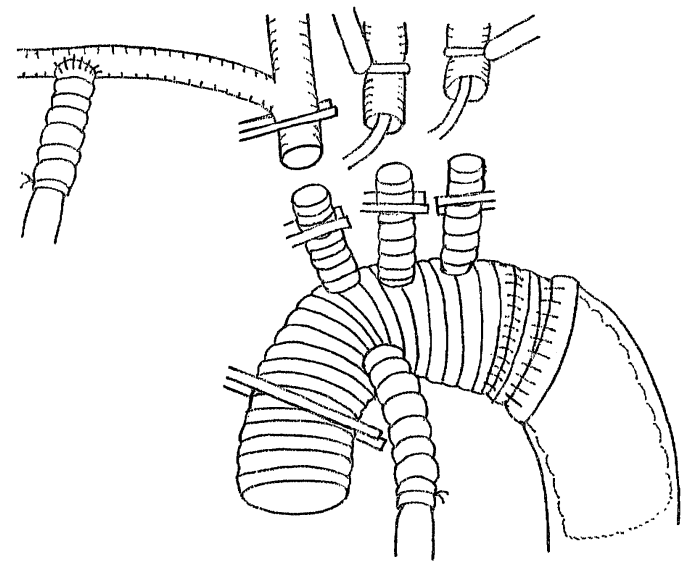

図 1 手術シェーマ

右腋窩動脈送血, 脳分離体外循環による弓部大動脈全置換術. 末梢側吻合は elephant trunk 法で行う。

表 1 患者背景

\begin{tabular}{llr}
\hline 手術時年齢 & $72 \pm 5$ 歳 $(65 \sim 80$ 歳 $)$ & \\
性別 & 男性 & 12 例 \\
& 女性 & 0 例 \\
疾患 & 遠位弓部大動脈瘤 & 11 例 \\
術式 & 上行弓部大動脈溜 & 1 例 \\
& 全弓部置換術 & 10 例 \\
同時手術 & パッチ形成術 & 2 例 \\
腋窩動脈送血手技直接ガニュレーション & 2 例 \\
& CABG & 1 例 \\
& 人工血管縫着 & 10 例 \\
\hline
\end{tabular}

胸アプローチ症例および逆行性脳灌流を行った症例は除外 した。手術時年齢は 65〜80 歳, 平均 72 歳, すべて男性で あった，遠位弓部大動脈瘤が 11 例，上行弓部大動脈瘤が 1 例であった。術式は全弓部置換術 10 例，パッチ形成術 2 例であった．同時手術として冠動脈バイパスを 2 例，F-F バイパスを 1 例に施行した。右腋窩動脈送血に関して, 直 接動脈にカニュレーションを行ったのが 2 例，あらかじめ 人工血管を縫着し送血路としたのが 10 例であった。これ らに対して手術成績を術後脳合併症の発生を中心に検討し た。

\section{結果}

手術時間 $479 \pm 98$ 分 (350 692 分)，人工心肺時間 $207 \pm 50$ 分 (155 285 分)，脳分離体外循環時間 $99 \pm 40$ 分 (52 151 分)，心停止時間 $80 \pm 16$ 分 (52 102 分), 下半 身循環停止時間 $55 \pm 10$ 分（40 74 分）おうび最低直腸温 $\left.21.7 \pm 1.8^{\circ} \mathrm{C} （ 18.5 \sim 24.1^{\circ} \mathrm{C}\right)$ であった（表 2$)$. 術前の脳 神経系の合併症として, 左内頸動脈閉塞に起因した脳梗塞 の既往を 1 例に認めた．麻痺などの神経学的症状を有する 症例はなかった。術後は，術前から脳梗塞を認めた 1 例に
表 2 結果

\begin{tabular}{lrl}
\hline 手術時間 & $479 \pm 98$ 分 $(350 \sim 692$ 分 $)$ \\
人工心肺時間 & $207 \pm 50$ 分 $(155 \sim 285$ 分 $)$ \\
脳分離体外循環時間 & $99 \pm 40$ 分 $(52 \sim 151$ 分 $)$ \\
心停止時間 & $80 \pm 16$ 分 $(52 \sim 102$ 分 $)$ \\
下半身循環停止時間 & $55 \pm 10$ 分 $(40 \sim 74$ 分 $)$ \\
最低直腸温 & $21.7 \pm 1.8^{\circ} \mathrm{C}\left(18.5 \sim 24.1^{\circ} \mathrm{C}\right)$ \\
\hline
\end{tabular}

送血側とは対側の左側の脳梗塞を発症，手術死亡となっ た。軽度譫妄を 3 例に認めたが，いずれも短期間で改善し た。譫妄をきたした 3 例を含めて術後合併症を認めず，脳 梗塞を発症した 1 例以外は全例軽快退院した。

\section{考察}

胸部大動脈瘤手術における体外循環の送血経路として, 真性，解離性を問わず大腿動脈が最も広く用いられている が，体循環が逆行性仂えの合併症 ${ }^{2)}$ が危惧される，真性瘤 のように全身性の動脈硬化性病変が著しい場合, 逆行性送 血に伴う術中塞栓遊離による脳梗塞の発症の可能性が指摘 されている1)。また術中逆行性解離発生にも注意を要す る. 他の合併症としても下肢虚血, 神経傷害, リンパ漏お よび創治癒遅延などがあげられ，動脈硬化性病変の著明な 真性瘤の治療成績に大きく関与している。

高度の動脈硬化などの原因により上行大動脈カニュレー ションが不可能な心臟手術に抢ける送血経路として, 腋窩 動脈は大腿動脈とともに以前から使用されてきた 循環の送血経路としての腋窩動脈の利点は，血流の方向が 順行性であることである。順行性送血を行うことで血流の 方向は生理的に保たれ，動脈硬化性病変を有する大腿動 脈，腸骨動脈および大動脈の debris が脳および腹部臟器 へ遊離することを防止できる ${ }^{3,5}$. また脳保護を必要とす る胸部大動脈瘤手術時の腋窝動脈送血のさらなる利点は脳 分離体外循環時の右総頸動脈送血経路としてそのまま使用 可能な点である．全身性の動脈硬化症例では腸骨動脈から 大腿動脈はしばしば冒されるが，腋窩動脈に及ぶことはま れである ${ }^{6)}$. 送血を順行性に行う観点から，CT および術 中エコーで安全性を確認し上行大動脈送血を選択する考え もあるが，とくに真性瘤では動脈硬化病変は上行大動脈以 外の弓部分枝起始部にも存在し，粥状硬化性病変が十分に 把握できないことがある，真性胸部大動脈瘤に対して右腋 窩動脈送血を行うにさいしては, 胸部 CT と血管造影で腕 頭動脈分岐部に有意な狭窄病変がないことを確認し，右上 肢血圧が左側に比べ低い場合は対側の腋窩動脈を用いる方 針としている．また脳分離体外循環時には腕頭動脈の遮断 が必要だが，CT および触診所見で遮断が不適当と判断さ れた場合はやむを得ず，上行大動脈送血としている。一 方，大動脈解離症例においても腋窩動脈へ解離が波及する 
ことはまれであり7)，真腔送血の観点からも本法は有用で ある。

われわれの真性胸部大動脈瘤に対する術式選択は，弓部 に病変を有する症例には積極的に病変部を残すことなく広 範囲に上行弓部大動脈全置換を行うことを基本方針として いる.今回検討の初期の症例を含を以前の症例では，弓部 大動脈囊状瘤に対しパッチ形成術を選択する等，手術侵襲 を可及的に小さくすることを考慮していたが，術式を定型 化し安定した成績が得られるようになった現在では全例に 弓部大動脈全置換術を採用している.

腋窝動脈からの送血法に関しては，弓部置換用の 4 分枝

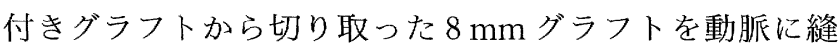
着している，この方法はカニューレによる血管損傷を防ぐ とともに右上肢への血流が維持される利点も有する7). ま た腋窩動脈送血で体循環の total flow を得られなかった経 験はなく，十分な流量を得ることが可能である．腋窩動脈 送血の短所として，まれに腕神経叢損傷や腋窩動脈血栓症 の可能性がある。Sabik らの報告では腋窩動脈送血関連合 併症は 34 症例中，右上肢のしびれ感を伴った腕神経叢損 傷が 1 例, 3 回目の腋窩動脈送血使用例の術後血栓症が 1 例であった . 今回の検討でも創感染を含めた腋窩動脈送 血に関連した合併症は 1 例も認めなかった。しかし Imanaka らは, 解離症例に対する腋窩動脈送血時の腕頭 動脈解離発症による脳梗塞 ${ }^{8)}$ を報告しており今後注意が必 要である。

以前は現在の治療方針を確立するまで大腿動脈送血を 行ってきたが，真性弓部大動脈瘤手術後に約 30\%ほどの 脳梗塞発症を認めていた。しかし腋窩動脈送血を採用，弓 部全置換を標準術式としてからの 12 症例中，術後脳梗塞 の発症は内頸動脈閉塞に起因した術前脳梗塞を伴った 1 例 のみであり，脳合併症の減少を図るという目的はほぼ達せ
られたと考えている。こうした補助手段の改良と定型化お よび弓部全置換の積極的導入により，脳合併症ひいては手 術死亡率の低下が可能になったと考えられた。

\section{結語}

真性胸部大動脈瘤手術における腋窩動脈送血と弓部全置 換の積極的導入により死亡率と脳合併症は減少した．腋窩 動脈送血と手術手技の改善により，動脈硬化性病変が著し い本症でも比較的安全に手術が行えると考えられた。

\section{文献}

1）安藤太三, 安達盛次, 中谷 充ほか：動脈硬化性の遠位弓部 大動脈瘤に対する手術成績の検討。日胸外会誌 41：20342039, 1993.

2）種元和雄, 杭ノ瀬昌彦, 金岡祐司：弓部関連大動脈手術時の 大腿動脈送血による合併症とその予防策. 日胸外会誌 42 ： 306-310, 1994.

3) Sabik, J. F., Lytle, B. W., McCarthy, P. M. et al.: Axillary artery: An alternative site of arterial cannulation for patients with extensive aortic and peripheral vascular disease. J. Thorac. Cardiovasc. Surg. 109 : 885-891, 1995

4) Borst, H. G. : Axillary artery for extracorporeal circulation [Letter]. J. Thorac. Cardiovasc. Surg. 110 : 1775, 1995.

5) Baribeau, Y. R., Westbrook, B. M., Charlesworth, D. C. et al. : Arterial inflow via an axillary artery graft for the severely atheromatous aorta. Ann. Thorac. Surg. 66 : 33-37, 1998.

6) Bichell, D. P., Balaguer, J. M., Aranki, S. F. et al. : Axilloaxillary cardiopulmonary bypass : A practical alternative to femorofemoral bypass. Ann. Thorac. Surg. 64: 702-705, 1997.

7) Whitlark, J. D., Goldman, S. M. and Sutter, F. P.: Axillary artery cannulation in acute ascending aortic dissections. Ann. Thorac. Surg. 69 : 1127-1129, 2000.

8) Imanaka, K., Kyo, S., Tanabe, H. et al. : Fatal intraoperative dissection of the innominate artery due to perfusion through the right axillary artery. J. Thorac. Cardiovasc. Surg. 120 : 405-406, 2000. 